\title{
Determining a Threshold to Delimit the Amazonian Forests from the Tree Canopy Cover 2000 GFC Data
}

\author{
Kaio Allan Cruz Gasparini ${ }^{1, t, * \mathbb{C}}$, Celso Henrique Leite Silva Junior ${ }^{1,+}+\mathbb{B}$, \\ Yosio Edemir Shimabukuro ${ }^{1}$, Egidio Arai ${ }^{1}$, Luiz Eduardo Oliveira Cruz e Aragão ${ }^{1}(\mathbb{D}$, \\ Carlos Alberto Silva ${ }^{2}$ (D) and Peter L. Marshall ${ }^{3}$ (D) \\ 1 Divisão de Sensoriamento Remoto, Instituto Nacional de Pesquisas Espaciais, São José dos Campos - SP, \\ Brazil; celso.junior@inpe.br (C.H.L.S.J.); yosio.shimabukuro@inpe.br (Y.E.S.); egidio.arai@inpe.br (E.A.); \\ luiz.aragao@inpe.br (L.E.O.C.eA.) \\ 2 Department of Geographical Sciences, University of Maryland, College Park, Maryland, MD 20740, USA; \\ carlos_engflorestal@outlook.com \\ 3 Department of Forest Resources Management, The University of British Columbia, 2424 Main Mall, \\ Vancouver, BC V6T 1Z4, Canada; peter.marshall@ubc.ca \\ * Correspondence: kaioallangasparini@gmail.com \\ + These authors contributed equally to this work.
}

Received: 2 September 2019; Accepted: 13 November 2019; Published: 18 November 2019

\begin{abstract}
Open global forest cover data can be a critical component for Reducing Emissions from Deforestation and Forest Degradation (REDD+) policies. In this work, we determine the best threshold, compatible with the official Brazilian dataset, for establishing a forest mask cover within the Amazon basin for the year 2000 using the Tree Canopy Cover 2000 GFC product. We compared forest cover maps produced using several thresholds $(10 \%, 30 \%, 50 \%, 80 \%, 85 \%, 90 \%$, and $95 \%$ ) with a forest cover map for the same year from the Brazilian Amazon Deforestation Monitoring Project (PRODES) data, produced by the National Institute for Space Research (INPE). We also compared the forest cover classifications indicated by each of these maps to 2550 independently assessed Landsat pixels for the year 2000, providing an accuracy assessment for each of these map products. We found that thresholds of $80 \%$ and $85 \%$ best matched with the PRODES data. Consequently, we recommend using an $80 \%$ threshold for the Tree Canopy Cover 2000 data for assessing forest cover in the Amazon basin.
\end{abstract}

Keywords: forest mapping; Google Earth Engine; REDD+; remote sensing; forest degradation

\section{Introduction}

Tropical forests play an essential role in the carbon (C) cycle [1]. However, human actions through deforestation and forest degradation can revert the natural tropical forest $C$ sink. It is estimated that deforestation is the second largest source of $\mathrm{C}$ emission into the atmosphere, emitting between 0.81 and $1.14 \mathrm{Pg} \mathrm{C}$ annually [2-5]. Degradation is another important driver of carbon emission within tropical regions. In the Amazon, during drought years, $\mathrm{C}$ emissions from forest fires can exacerbate old-growth forest deforestation emissions by more than half [6].

Brazil has been monitoring the extent of the Amazon rainforest since the late 1980s using Landsat images available through the Brazilian Amazon Deforestation Monitoring Project (PRODES), a project operated by the Brazilian National Institute of Space Research in collaboration with the Ministry of the Environment and the Brazilian Institute of Environment and Natural Resources [7]. Since deforestation is the second largest $\mathrm{CO}_{2}$ emission driver [8], PRODES allowed Brazil to be a pioneer in reducing emissions under the Reducing Emissions from Deforestation and Forest Degradation $(\mathrm{REDD}+)$ policy [9]. For the correct monitoring of forest areas, there is a need to draw a baseline, 
or year of reference, to begin monitoring. Consequently, a map representing the forest area at the beginning of forest monitoring is important [10]. With the baseline forest (a forest mask) established, one can quantify new deforestation as well as degraded areas by identifying the affected areas on the initial map. Recently, such forest monitoring initiatives have gained popularity [11,12], especially after the emergence of remote sensing applications using cloud computing as a platform [13].

The Google Earth Engine platform has allowed studies on a planetary scale [14]. To date, the uses of the Google Earth Engine have been diverse, such as mapping malaria risks [15], environmental monitoring [13,16], and urban mapping [17,18]. Hansen et al. [13] were among the first researchers to use the Google Earth Engine platform. They mapped forest changes worldwide from 2000 to 2013 using Landsat imagery collection (30 m of spatial resolution). In the current version of the mapping engine (v1.6), the authors processed images up to 2018 [19]. A highlight of their research was the construction of a raster map of the 2000 baseline named 'Tree Canopy Cover 2000 GFC Data' (TreeCover2000). TreeCover2000 represents tree cover for the year 2000 at a 30-meter spatial resolution. These data were generated using multispectral satellite imagery from the Landsat 7 thematic mapper plus (ETM+) sensor [13,20]. Cloud-free observations from over 600,000 images were analyzed using Google Earth Engine to determine per-pixel tree cover using a supervised machine learning algorithm (regression tree approach) $[13,20]$. The regression tree training data were obtained from Ikonos (4 m of spatial resolution) and QuickBird (2.8 m of spatial resolution) image classifications, in which tree cover was transformed to percent values [21,22]. The result was a map of percentage values of tree cover, ranging from $0 \%$ to $100 \%$, where $0 \%$ represented no tree cover and $100 \%$ represented maximum tree cover for a pixel. These data require a user to choose a percentage threshold value to determine whether a pixel is considered forest (i.e., cover value equal to or greater than the threshold). Several thresholds have been empirically chosen in the literature to define forest cover with the TreeCover2000 data. For example: Grecchi et al. [23], Taubert et al. [24], Brinck et al. [25], and Esquivel-Muelbert et al. [26] used 30\%; Shimabukuro et al. [27] used 50\%; Wagner et al. [28] used 80\%; and Tyukavina et al. [29] used $83 \%$. However, as far as we know, no study has focused on testing the performance of these thresholds in delimiting the Amazonian rainforests in order to match with other countries' definition of forest. Without a threshold standardization, comparisons among studies and with official statistics become impossible.

Bearing in mind that the Amazonian forest extends beyond Brazil's borders and, apart from Brazil, few other Amazonian countries have long-term, large-scale forest mapping projects in place, the use of the TreeCover2000 dataset is essential for establishing baselines of intact forest areas. It is also valuable to have measurements that are comparable across countries. However, it is not clear what threshold would best delimit Amazonian forests. To answer this question, we compared the PRODES forest cover map with maps produced using different thresholds of the TreeCover2000 data for an area within the Brazilian portion of the Amazon basin. We also compared the classifications in all the maps to 2550 independently assessed Landsat pixels indicating forest coverage in the year 2000.

\section{Materials and Methods}

\subsection{Study Area}

We used the Brazilian state of Mato Grosso (Figure 1) for this analysis due to its physiographic heterogeneity. Mato Grosso includes flooded fields (Pantanal), natural fields and savannas (Cerrado), and deciduous and evergreen forests (Amazonia) [30]. This region is also part of the "arc of deforestation", an area of intense deforestation that borders the Cerrado [31] and recently considered a consolidated agricultural frontier [32]. Consequently, Mato Grosso is potentially the only place that provides the full range of phytophysiognomies found in the Amazon basin as a whole. 

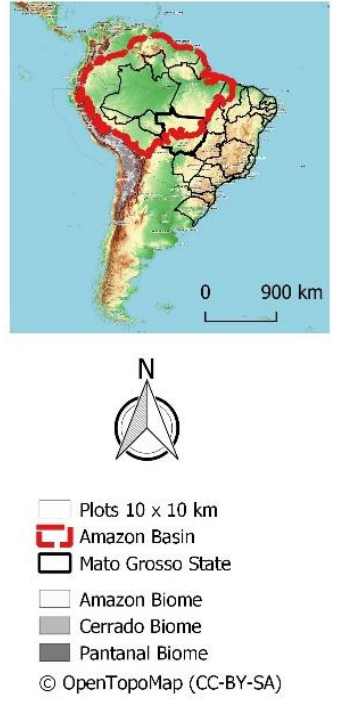

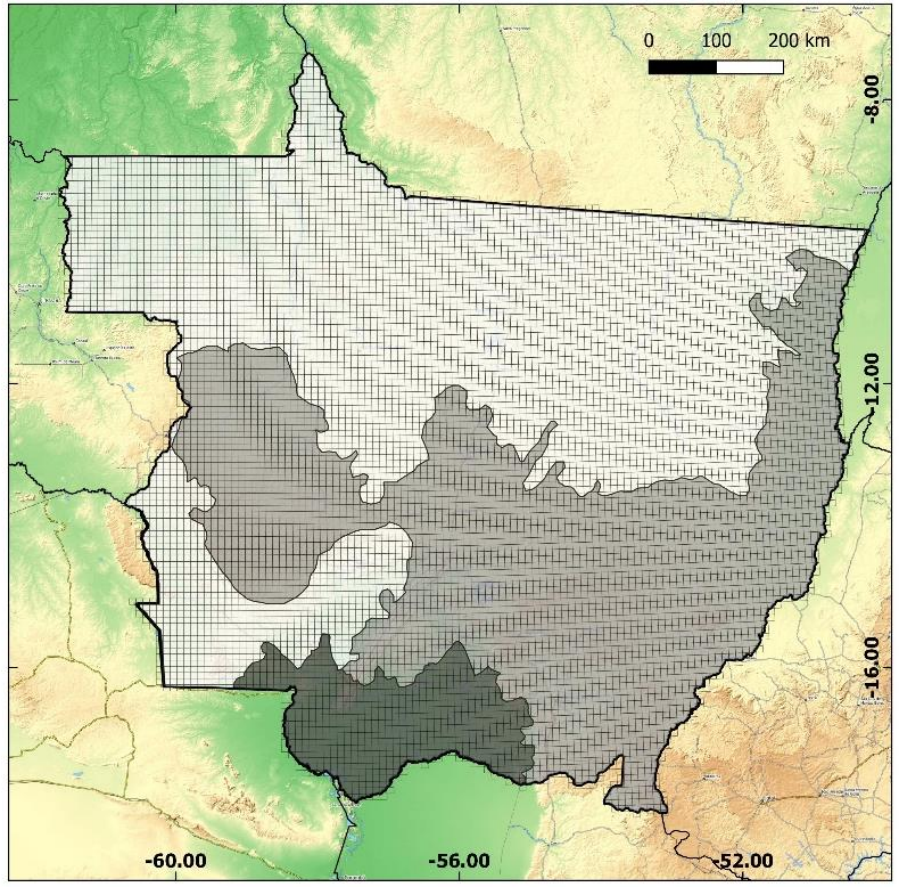

Figure 1. Location of the state of Mato Grosso, representative biomes, and the spatial distribution of the $10 \mathrm{~km}^{2}$ plots used as samples. The smaller map shows the extent of the Amazon basin [33].

\subsection{Datasets}

The Tree Canopy Cover 2000 GFC data (TreeCover2000) were obtained from the Global Forest Change website [19]. These data represent the percentage of all vegetation greater than $5 \mathrm{~m}$ in height, not necessarily natural forest, with values ranging from $0 \%$ (no vegetation greater than $5 \mathrm{~m}$ in height) to $100 \%$ (total cover) [13]. The global dataset is divided into 10-degree by 10-degree segments (tiles). Four such tiles were necessary to get complete coverage of Mato Grosso (00N_060W, 00N_070W, 10S_60S, and 10S_70S). The spatial resolution of the data is 0.00025 degrees, which is equivalent to $30 \mathrm{~m}$ in the Equator region.

The PRODES data were obtained from [34]. The data have a 1:250,000 mapping scale and represent areas of old-growth forests mapped manually from radar and optical remote sensing data. We used the vector data from 2014. From that, we reconstructed the forest cover for the year 2000 by converting all deforested polygons from the period 2001 to 2014 back to forest, with the remainder labelled as non-forest. These data were then converted to a $30 \mathrm{~m}$ raster basis to be compatible with Tree Canopy Cover 2000 data.

An independent reference sample of forest and non-forest coverage in the study area was obtained from Tyukavina et al. [29,35]. In their study, 10,000 Landsat $(5,7$, and 8) $30 \mathrm{~m}$ pixels were classified over the period from 1999 to 2013 across the entire Brazilian Amazon. Of these sample pixels, 2550 were located in Mato Grosso. As this work is based on the year 2000, an external evaluator assessed each of the 2550 pixels in Mato Grosso and labelled each as forest or non-forest based on the year 2000 data.

\subsection{Methods}

About 932910 by $10 \mathrm{~km}$ plots (samples) were established across Mato Grosso (Figure 1). Of these plots, 4994 (53\%) were in the Amazon biome, 3703 (40\%) were in the Cerrado biome, and 632 (7\%) were in the Pantanal biome. Initially, we calculated the forest cover percentage from the PRODES data within each of the 9329 plots. Then, we calculated the forest cover proportion from the Tree Canopy Cover 2000 maps, which used the following thresholds: (1) greater than $10 \%$; (2) greater than $30 \%$; (3) greater than $50 \%$; (4) greater than $80 \%$; (5) greater than $85 \%$; (6) greater than $90 \%$; and (7) greater than $95 \%$. Any pixel that exceeded these thresholds was considered as forest. We selected these thresholds based 
on preliminary tests and the previous studies from the literature $[23,24,26-29]$, representing a wide range of thresholds. Hereafter, we refer to these thresholds as $10 \%, 30 \%$, and so on.

The proportions of forest cover within each of the 9329 plots defined by each threshold and the PRODES forest cover were compared using linear regression, suggested by Shimabukuro et al. [30]. This method is a robust and straightforward approach to validating remote sensing mapping. The coefficient of determination $\left(R^{2}\right)$, intercept, slope, and the root mean squared error (RMSE) were used for comparison among the various regression equations to determine the best threshold to use. The ideal value for $\mathrm{R}^{2}$ was 1,0 for the intercept, 1 for the slope, and 0 for the RMSE. We used the bootstrap method for this analysis. In this approach, 10,000 interactions were performed, where each interaction was randomly raffled $10 \%$ of the 9329 plots with replacement. Then, the means and standard deviations of the $10,000 \mathrm{R}^{2}$, intercept, slope, and the RMSE were calculated. All analyses were performed using the $\mathrm{R}$ statistical software package [36]. To calculate the forest proportion within each of the 10 by $10 \mathrm{~km}$ plots, the "lsm_c_pland" function of the "landscapemetrics" package [37] was used. Linear regressions were performed using the "ln" native function of the R software.

Moreover, we built a confusion matrix that was used to tabulate the differences in classification between the maps and the reference samples using the "Accuracy Assessment" tool [38], developed by the Food and Agriculture Organization of the United Nations (FAO), from the 2550 Landsat sample pixels (year 2000) provided by Tyukavina et al. [29]. As suggested by Olofsson et al. [39] and the FAO [38], we determined a weighted matrix error using the ratio of the area of each class sampled over the total area of each class (Equation (1)). This weighted error was then used to calculate the standard error (Equation 2) and the confidence interval for the estimated area of each class,

$$
\begin{gathered}
\hat{p}_{i, j}=\frac{W_{i} \cdot n_{i, j}}{n_{i}} \\
S(\hat{p})=\sqrt{\sum_{i} \frac{W_{i} \cdot \hat{p}_{i, j}-\hat{p}_{i, j}^{2}}{n_{i}-1}}
\end{gathered}
$$

where $\hat{p}_{i, j}$ is the proportional area for each cell in the matrix, $W_{i}$ corresponds to the class weights (the proportional area of class $\mathrm{i}), n_{i, j}$ is the sample count in cell $\mathrm{i}, \mathrm{j}, n_{i}$ is the total sample count in class $\mathrm{i}$, and $S(\hat{p})$ is the standard error of the area estimates assuming simple random sampling.

\section{Results}

Our analyses revealed that the lower thresholds $(10 \%, 30 \%$, and $50 \%)$ included forest cover in areas covered by savanna vegetation within the Cerrado biome (see Figure 1) [40], in the south-central portion of Mato Grosso (see Figures 2 and 3) [40]. Maps produced using the 80\%, 85\%, and 90\% thresholds showed greater visual similarity to the PRODES forest map (Figures 2 and 3). 

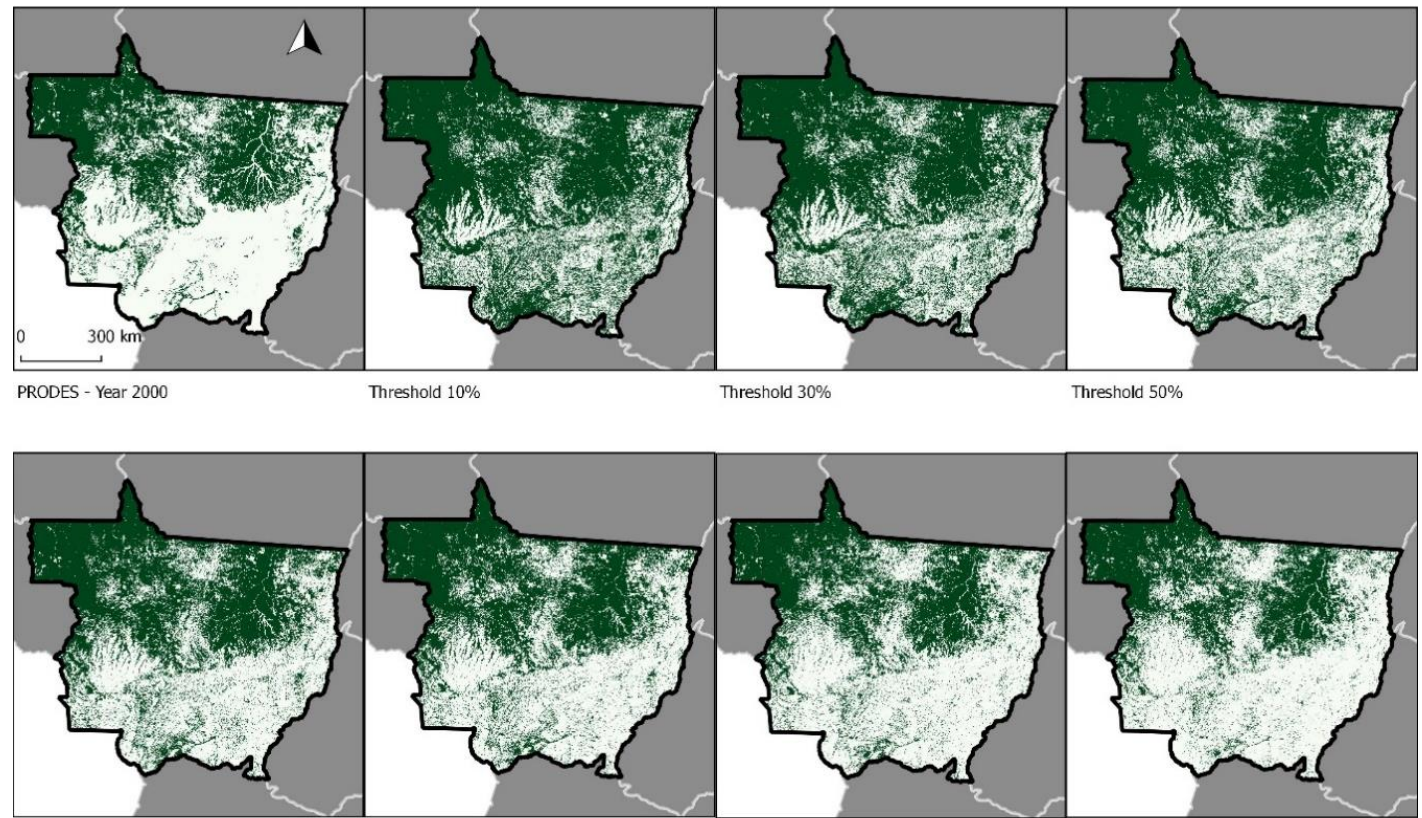

Threshold 80\%

Threshold 85\%

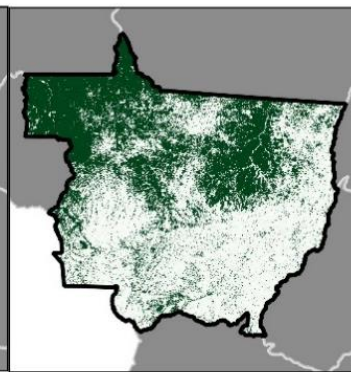

Threshold 90\%

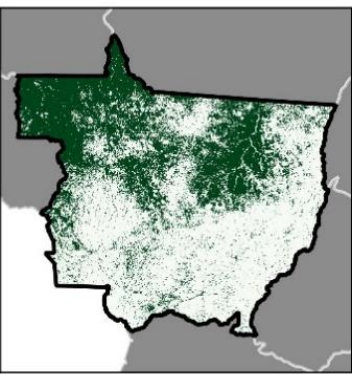

Threshold 95\%

No Fores

Forest

Figure 2. Spatial arrangement of each threshold assessed in the study compared to the Brazilian Amazon Deforestation Monitoring Project (PRODES) data.

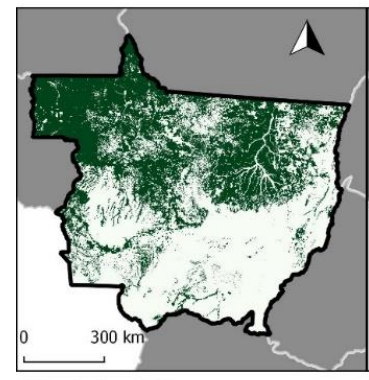

PRODES - Year 2000

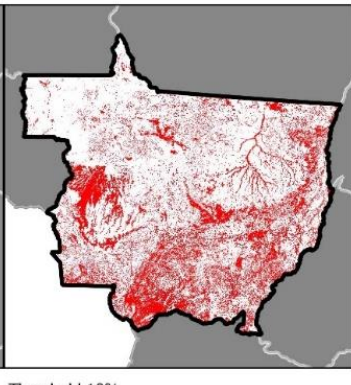

Threshold 10\%

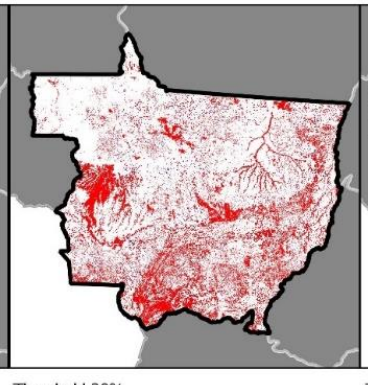

Threshold 30\%

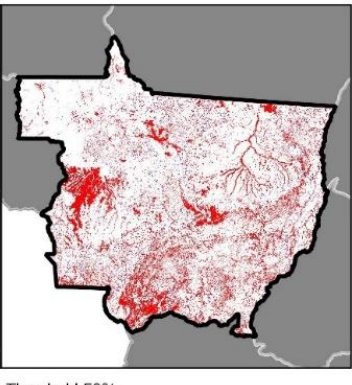

Threshold 50\%

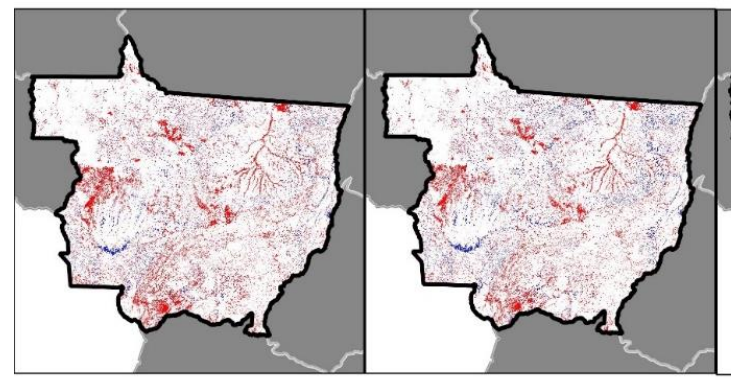

Threshold $80 \%$

Threshold $85 \%$

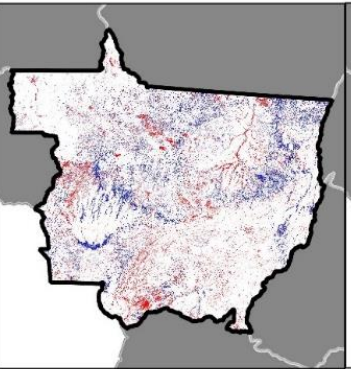

Threshold $90 \%$

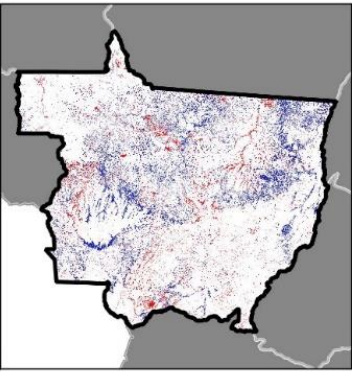

Threshold $95 \%$

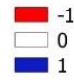

Figure 3. Maps of differences between spatial arrangements of each threshold assessed in the study compared to the PRODES data. Red (-1) represents pixels that were non-forest cover using PRODES and forest cover using the Tree Canopy Cover 2000 data. White (0) represents pixels classified into the same class using both datasets. Blue (1) represents pixels that were classified as forest cover using PRODES and non-forest cover using Tree Canopy Cover 2000 data. 
As expected, the 95\% threshold map indicated the smallest forest cover, about 37\% of Mato Grosso, and the $10 \%$ threshold map indicated the largest forest cover, about $66 \%$ of Mato Grosso (Table 1 ). The PRODES map indicated approximately 41\% of forest cover within Mato Grosso in 2000, which was most closely matched by the $90 \%$ threshold.

Table 1. Forest cover assessment for the year 2000 in Mato Grosso, Brazil, according to the PRODES map and maps produced using various thresholds with the Tree Canopy Cover 2000 data.

\begin{tabular}{ccc}
\hline Map & Forest (\%) & Non-Forest (\%) \\
\hline PRODES map & 41 & 59 \\
10\% Threshold & 66 & 34 \\
30\% Threshold & 63 & 37 \\
50\% Threshold & 58 & 42 \\
80\% Threshold & 49 & 51 \\
85\% Threshold & 47 & 53 \\
90\% Threshold & 40 & 60 \\
95\% Threshold & 37 & 63 \\
\hline
\end{tabular}

We found that forest cover maps produced from the $10 \%, 30 \%$, and $50 \%$ thresholds tended to overestimate forest cover based on the 9329 sample plots, as evidenced by the concentration of the majority of the points above the 1:1 line (Figure 4). The maps produced using thresholds of $90 \%$ and 95\% underestimated forest cover, as more points fell below the 1:1 line than above it. Finally, the forest maps produced using the $80 \%$ and $85 \%$ thresholds showed a more even dispersion of points around the regression line and the 1:1 line.

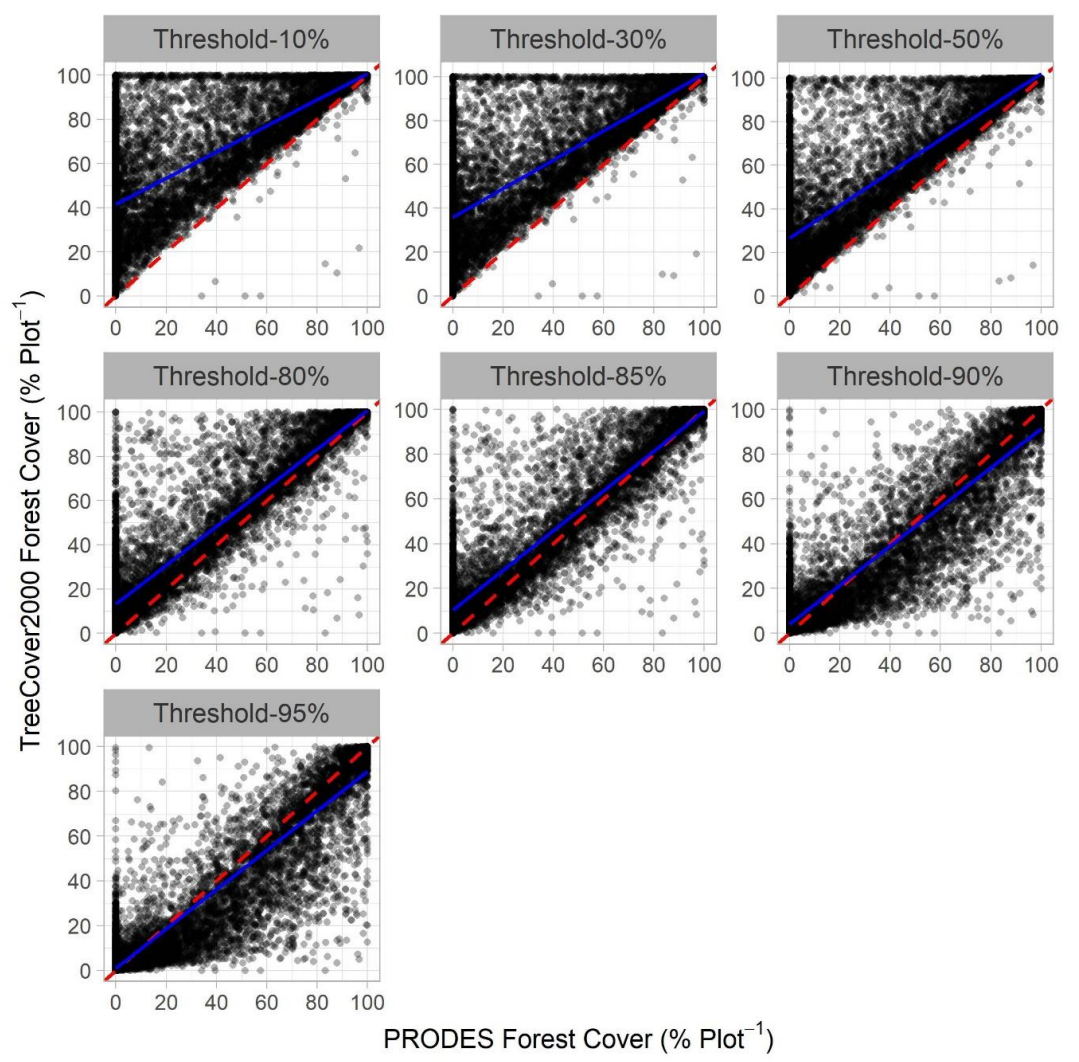

Figure 4. Regression between the forest percentage within all of 9329 (10 by $10 \mathrm{~km}$ ) samples cells using different thresholds from the Tree Canopy Cover 2000 data and their corresponding percentages on a reference map developed using the PRODES data. The dashed red line is the 1:1 line. The blue line is the average regression line from 10,000 interactions for each threshold tested. 
All the 10,000 regressions were significant at a level of $1 \%$ ( $p$-values less than 0.001$)$. The $\mathrm{R}^{2}$ increased from an average of $0.612 \pm 0.021$ to $0.869 \pm 0.013$ for $10 \%$ and $85 \%$, respectively. The intercept coefficient values decreased from an average of $41.560 \pm 1.058$ for the $10 \%$ threshold to an average of $0.978 \pm 0.473$ for the $95 \%$ threshold. At the same time, the slope coefficient values increased from an average of $0.591 \pm 0.013$ for the $10 \%$ threshold to an average of $0.888 \pm 0.009$ for the $85 \%$ threshold. Finally, the RMSE had a lower average of $13.060 \pm 0.644$ for the $85 \%$ threshold, and a higher average of $17.910 \pm 0.498$ for the $10 \%$ threshold.

The accuracy assessment results showed that the poorest match (lowest overall accuracy) was obtained with the $95 \%$ threshold $(71 \%)$ and the best match (highest overall accuracy) was obtained with the 50\% threshold (87\%) (Table 2). The PRODES data had the third lowest match (74\%), albeit slightly higher than the $90 \%$ threshold. The $80 \%$ threshold best matched with the PRODES data in terms of the estimated cover of non-forest and forest in Mato Grosso.

Table 2. Result from 10,000 bootstrap interactions. Intercept, slope, coefficient of determination $\left(\mathrm{R}^{2}\right)$, root mean squared error (RMSE), and $p$-values of the linear regressions are used for comparing the tested thresholds to the PRODES data. SD is the standard deviation.

\begin{tabular}{cccccc}
\hline Threshold & $\mathbf{R}^{\mathbf{2}}( \pm \mathbf{S D})$ & Intercept $( \pm \mathbf{S D})$ & Slope $( \pm \mathbf{S D})$ & RMSE $( \pm \mathbf{S D})$ & $p$-value $( \pm$ SD) \\
\hline $10 \%$ & $0.612 \pm 0.021$ & $41.560 \pm 1.058$ & $0.591 \pm 0.013$ & $17.910 \pm 0.498$ & $0 \pm 0$ \\
$30 \%$ & $0.669 \pm 0.020$ & $35.870 \pm 1.029$ & $0.655 \pm 0.013$ & $17.520 \pm 0.542$ & $0 \pm 0$ \\
$50 \%$ & $0.752 \pm 0.019$ & $26.630 \pm 0.953$ & $0.755 \pm 0.012$ & $16.500 \pm 0.620$ & $0 \pm 0$ \\
$80 \%$ & $0.860 \pm 0.014$ & $13.290 \pm 0.693$ & $0.874 \pm 0.009$ & $13.380 \pm 0.646$ & $0 \pm 0$ \\
$85 \%$ & $0.869 \pm 0.013$ & $10.351 \pm 0.693$ & $0.888 \pm 0.009$ & $13.060 \pm 0.644$ & $0 \pm 0$ \\
$90 \%$ & $0.857 \pm 0.013$ & $4.120 \pm 0.513$ & $0.872 \pm 0.010$ & $13.540 \pm 0.550$ & $0 \pm 0$ \\
$95 \%$ & $0.852 \pm 0.013$ & $0.978 \pm 0.473$ & $0.879 \pm 0.010$ & $13.960 \pm 0.010$ & $0 \pm 0$ \\
\hline
\end{tabular}

Not surprisingly, the highest user's accuracy (85\%) for non-forest cover was obtained with the 10\% threshold and declined with increasing threshold size (Table 3). The highest user's accuracy (99\%) for forest cover was found with the $95 \%$ threshold and declined with decreasing thresholds. The pattern for the producer's accuracy was the opposite of that of the user's accuracy. The highest producer's accuracy for non-forest cover (99\%) was found for the 95\% threshold and the highest producer's accuracy for forest cover (94\%) was found for the 10\% threshold. The thresholds that best resembled those obtained by the PRODES data were 85\% (user's accuracy) and 50\% (producer's accuracy). 
Table 3. Error matrix, accuracy, and confidence interval for each class (forest and non-forest) at each threshold compared to the PRODES data.

\begin{tabular}{|c|c|c|c|c|c|c|c|c|}
\hline \multirow{2}{*}{ Predictions } & \multirow{2}{*}{ Class } & \multicolumn{2}{|c|}{ Observed } & \multirow{2}{*}{$\begin{array}{c}\text { Estimated Area } \\
(\%)\end{array}$} & \multirow{2}{*}{$\begin{array}{l}\text { Estimated Area } \pm 95 \% \\
\text { Confidence }\left(\mathrm{km}^{2}\right)\end{array}$} & \multirow{2}{*}{$\begin{array}{c}\text { User's Accuracy } \\
\text { (\%) }\end{array}$} & \multirow{2}{*}{$\begin{array}{c}\text { Producer's } \\
\text { Accuracy (\%) }\end{array}$} & \multirow{2}{*}{$\begin{array}{c}\text { Overall } \\
\text { Accuracy }(\%)\end{array}$} \\
\hline & & Non-Forest & Forest & & & & & \\
\hline \multirow{2}{*}{$10 \%$} & Non-forest & 544 & 96 & 39.3 & $352,159 \pm 12,849$ & 85 & 64 & \multirow[b]{2}{*}{84} \\
\hline & Forest & 300 & 1601 & 60.7 & $543,914 \pm 12,849$ & 84 & 94 & \\
\hline \multirow{2}{*}{$30 \%$} & Non-forest & 600 & 118 & 39.4 & $353,006 \pm 12,606$ & 84 & 71 & \multirow{2}{*}{86} \\
\hline & Forest & 244 & 1579 & 60.6 & $543,067 \pm 12,606$ & 87 & 93 & \\
\hline \multirow[b]{2}{*}{$50 \%$} & Non-forest & 688 & 186 & 38.6 & $346,277 \pm 12,568$ & 79 & 82 & \multirow[b]{2}{*}{87} \\
\hline & Forest & 156 & 1511 & 61.4 & $549,796 \pm 12,568$ & 91 & 74 & \\
\hline \multirow[b]{2}{*}{$80 \%$} & Non-forest & 787 & 389 & 36.0 & $322,227 \pm 13,082$ & 67 & 93 & \multirow[b]{2}{*}{82} \\
\hline & Forest & 57 & 1308 & 64.0 & $573,846 \pm 13,082$ & 96 & 77 & \\
\hline \multirow{2}{*}{$85 \%$} & Non-forest & 803 & 461 & 35.2 & $315,401 \pm 13,256$ & 64 & 95 & \multirow{2}{*}{80} \\
\hline & Forest & 41 & 1236 & 64.8 & $580,672 \pm 13,256$ & 97 & 73 & \\
\hline \multirow{2}{*}{$90 \%$} & Non-forest & 821 & 651 & 34.3 & $307,281 \pm 13,985$ & 56 & 97 & \multirow{2}{*}{73} \\
\hline & Forest & 23 & 1046 & 65.7 & $588,792 \pm 13,985$ & 98 & 62 & \\
\hline \multirow[b]{2}{*}{$95 \%$} & Non-forest & 832 & 737 & 33.6 & $302,454 \pm 14,090$ & 53 & 99 & \multirow[b]{2}{*}{71} \\
\hline & Forest & 12 & 960 & 66.4 & $593,618 \pm 14,090$ & 99 & 57 & \\
\hline \multirow[b]{2}{*}{ PRODES } & Non-forest & 748 & 572 & 36.6 & $327,194 \pm 15,134$ & 57 & 89 & \multirow[b]{2}{*}{74} \\
\hline & Forest & 96 & 1125 & 63.4 & $567.323 \pm 15,134$ & 92 & 66 & \\
\hline
\end{tabular}




\section{Discussion and Conclusions}

We compared Amazonian forest cover using Tree Canopy Cover 2000 and the PRODES data within a portion of the Amazon basin in Brazil. By creating several forest maps from applying thresholds to the Tree Canopy Cover 2000 data, we showed that there are relevant differences in the quantity and spatial distribution of forest cover depending on the threshold chosen. For instance, we found that thresholds of $80 \%$ and $85 \%$ for the Tree Canopy Cover 2000 data best matched the PRODES forest cover data across Mato Grosso State in Brazil. For example, the lower thresholds evaluated-between $10 \%$ and $50 \%$-overestimated forest cover, especially within savanna formations, where trees are sparser within the landscape. Thus, the choice of less conservative thresholds may inflate the quantification of forest disturbances, such as fires [27], deforestation [13], selective logging [23], forest fragmentation [24-26], and, consequently, carbon emissions accounting.

We emphasize that the choice of a threshold level for the Tree Canopy Cover 2000 data will depend on the nature of the application. If the change in forest cover through time is being assessed, then, obviously, consistency through time among threshold levels is more important than the threshold level ultimately chosen for the assessment. However, in general, based on our analyses, we recommend using an $80 \%$ threshold with the Tree Canopy Cover 2000 data for assessing forest cover in the Amazon basin.

The approach we presented may help countries currently involved in REDD+ in the Amazon region. Forest reference levels can be based on Tree Canopy Cover 2000 data using our suggested threshold (UNFCCC, 2010) [41]. Presently, Brazil, Colombia, Ecuador, Guyana, Peru, and Suriname are members of REDD+ [42]. A standardization of methods across countries would be beneficial for the evaluation of the effectiveness of countries' efforts to mitigate emissions from land cover change.

Author Contributions: K.A.C.G., C.H.L.S.J., and L.E.O.C.eA. designed the research. K.A.C.G., C.H.L.S.J., and E.A. processed the data. K.A.C.G., C.H.L.S.J, Y.E.S., P.L.M., and L.E.O.C.A. analyzed the results. K.A.C.G. and P.L.M. wrote the manuscript with inputs from C.H.L.S.J., C.A.S., and Y.E.S.

Funding: This study was financed in part by the Coordenação de Aperfeiçoamento de Pessoal de Nível Superior - Brasil (CAPES) - Finance Code 001. L.E.O.C.A. thanks Conselho Nacional de Desenvolvimento Científico e Tecnológico (CNPq) - Processo 305054/2016-3. 95/5000. Finally, the authors thank FAPESP (process 2016/19806-3) for funding part of the research.

Acknowledgments: K.A.C.G. thanks the support of the Government of Canada, by the ELAP scholarship. Finally, we also thank the editor and reviewers whose helpful comments and suggestions helped to improve and clarify this manuscript.

Conflicts of Interest: The authors declare no conflicts of interest.

\section{References}

1. Le Quéré, C.; Raupach, M.R.; Canadell, J.G.; Marland, G.; Le Quéré, C.; Raupach, M.R.; Canadell, J.G.; Marland, G.; Bopp, L.; Ciais, P.; et al. Trends in the sources and sinks of carbon dioxide. Nat. Geosci. 2009, 2, 831-836. [CrossRef]

2. $\quad$ van der Werf, G.R.; Morton, D.C.; DeFries, R.S.; Olivier, J.G.J.; Kasibhatla, P.S.; Jackson, R.B.; Collatz, G.J.; Randerson, J.T. $\mathrm{CO}_{2}$ emissions from forest loss. Nat. Geosci. 2009, 2, 737-738. [CrossRef]

3. Houghton, R.A.; House, J.I.; Pongratz, J.; van der Werf, G.R.; DeFries, R.S.; Hansen, M.C.; Le Quéré, C.; Ramankutty, N. Carbon emissions from land use and land-cover change. Biogeosciences 2012, 9, 5125-5142. [CrossRef]

4. Harris, N.L.; Brown, S.; Hagen, S.C.; Saatchi, S.S.; Petrova, S.; Salas, W.; Hansen, M.C.; Potapov, P.V.; Lotsch, A. Baseline Map of Carbon Emissions from Deforestation in Tropical Regions. Science 2012, 336, 1573-1576. [CrossRef] [PubMed]

5. Baccini, A.; Goetz, S.J.; Walker, W.S.; Laporte, N.T.; Sun, M.; Sulla-Menashe, D.; Hackler, J.; Beck, P.S.A.; Dubayah, R.; Friedl, M.A.; et al. Estimated carbon dioxide emissions from tropical deforestation improved by carbon-density maps. Nat. Clim. Chang. 2012, 2, 182-185. [CrossRef] 
6. Aragão, L.E.O.C.; Anderson, L.O.; Fonseca, M.G.; Rosan, T.M.; Vedovato, L.B.; Wagner, F.H.; Silva, C.V.J.; Silva Junior, C.H.L.; Arai, E.; Aguiar, A.P.; et al. 21st Century drought-related fires counteract the decline of Amazon deforestation carbon emissions. Nat. Commun. 2018, 9, 536. [CrossRef]

7. Monitoramento do Desmatamento da Floresta Amazônica Brasileira por Satélite. Available online: http: //www.obt.inpe.br/OBT/assuntos/programas/amazonia/prodes (accessed on 1 January 2019).

8. Aragão, L.E.O.C.; Poulter, B.; Barlow, J.B.; Anderson, L.O.; Malhi, Y.; Saatchi, S.; Phillips, O.L.; Gloor, E. Environmental change and the carbon balance of Amazonian forests. Biol. Rev. 2014, 89, 913-931. [CrossRef]

9. Hargita, Y.; Günter, S.; Köthke, M. Brazil submitted the first REDD+ reference level to the UNFCCC-Implications regarding climate effectiveness and cost-efficiency. Land Use Policy 2015, 55, 340-347. [CrossRef]

10. Shimabukuro, Y.E.; Arai, E.; Duarte, V.; Jorge, A.; dos Santos, E.G.; Gasparini, K.A.C.; Dutra, A.C. Monitoring deforestation and forest degradation using multi-temporal fraction images derived from Landsat sensor data in the Brazilian Amazon. Int. J. Remote Sens. 2019, 40, 5475-5496. [CrossRef]

11. Potapov, P.V.; Turubanova, S.A.; Hansen, M.C.; Adusei, B.; Broich, M.; Altstatt, A.; Mane, L.; Justice, C.O. Quantifying forest cover loss in Democratic Republic of the Congo, 2000-2010, with Landsat ETM+ data. Remote Sens. Environ. 2012, 122, 106-116. [CrossRef]

12. Hansen, M.C.; Stehman, S.V.; Potapov, P.V. Quantification of global gross forest cover loss. Proc. Natl. Acad. Sci. USA 2010, 107, 8650-8655. [CrossRef] [PubMed]

13. Hansen, M.C.; Potapov, P.V.; Moore, R.; Hancher, M.; Turubanova, S.A.; Tyukavina, A.; Thau, D.; Stehman, S.V.; Goetz, S.J.; Loveland, T.R.; et al. High-Resolution Global Maps of 21st-Century Forest Cover Change. Science 2013, 342, 850-853. [CrossRef] [PubMed]

14. Gorelick, N.; Hancher, M.; Dixon, M.; Ilyushchenko, S.; Thau, D.; Moore, R. Google Earth Engine: Planetary-scale geospatial analysis for everyone. Remote Sens. Environ. 2017, 202, 18-27. [CrossRef]

15. Sturrock, H.J.; Cohen, J.M.; Keil, P.; Tatem, A.J.; Le Menach, A.; Ntshalintshali, N.E.; Hsiang, M.S.; Gosling, R.D. Fine-scale malaria risk mapping from routine aggregated case data. Malar. J. 2014, 13, 421. [CrossRef] [PubMed]

16. Pekel, J.-F.; Cottam, A.; Gorelick, N.; Belward, A.S. High-resolution mapping of global surface water and its long-term changes. Nature 2016, 540, 418-422. [CrossRef] [PubMed]

17. Patel, N.N.; Angiuli, E.; Gamba, P.; Gaughan, A.; Lisini, G.; Stevens, F.R.; Tatem, A.J.; Trianni, G. Multitemporal settlement and population mapping from Landsat using Google Earth Engine. Int. J. Appl. Earth Obs. Geoinf. 2015, 35, 199-208. [CrossRef]

18. Zhang, Q.; Li, B.; Thau, D.; Moore, R. Building a better Urban picture: Combining day and night remote sensing imagery. Remote Sens. 2015, 7, 11887-11913. [CrossRef]

19. GFC-Global Forest Change. Available online: https://earthenginepartners.appspot.com/science-2013global-forest/download_v1.6.html (accessed on 1 January 2019).

20. GFW-Global Forest Watch Tree Cover 2000. Available online: http://data.globalforestwatch.org/datasets/ tree-cover-2000 (accessed on 1 January 2019).

21. Hansen, M.C.; DeFries, R.S.; Townshend, J.R.G.; Carroll, M.; Dimiceli, C.; Sohlberg, R.A. Global Percent Tree Cover at a Spatial Resolution of 500 Meters: First Results of the MODIS Vegetation Continuous Fields Algorithm. Earth Interact. 2003, 7, 1-15. [CrossRef]

22. Hansen, M.C.; Egorov, A.; Roy, D.P.; Potapov, P.; Ju, J.; Turubanova, S.; Kommareddy, I.; Loveland, T.R. Continuous fields of land cover for the conterminous United States using Landsat data: First results from the Web-Enabled Landsat Data (WELD) project. Remote Sens. Lett. 2011, 2, 279-288. [CrossRef]

23. Grecchi, R.C.; Beuchle, R.; Shimabukuro, Y.E.; Aragão, L.E.O.C.; Arai, E.; Simonetti, D.; Achard, F. An integrated remote sensing and GIS approach for monitoring areas affected by selective logging: A case study in northern Mato Grosso, Brazilian Amazon. Int. J. Appl. Earth Obs. Geoinf. 2017, 61, 70-80. [CrossRef]

24. Taubert, F.; Fischer, R.; Groeneveld, J.; Lehmann, S.; Müller, M.S.; Rödig, E.; Wiegand, T.; Huth, A. Global patterns of tropical forest fragmentation. Nature 2018, 554, 519-522. [CrossRef] [PubMed]

25. Brinck, K.; Fischer, R.; Groeneveld, J.; Lehmann, S.; Dantas De Paula, M.; Pütz, S.; Sexton, J.O.; Song, D.; Huth, A. High resolution analysis of tropical forest fragmentation and its impact on the global carbon cycle. Nat. Commun. 2017, 8, 14855. [CrossRef] [PubMed] 
26. Esquivel-Muelbert, A.; Bennett, A.C.; Sullivan, M.J.P.; Baker, J.C.A.; Gavish, Y.; Johnson, M.O.; Wang, Y.; Chambers-Ostler, A.; Lisli Giannichi, M.; Gomes, L.; et al. A Spatial and Temporal Risk Assessment of the Impacts of El Niño on the Tropical Forest Carbon Cycle: Theoretical Framework, Scenarios, and Implications. Atmosphere 2019, 10, 588. [CrossRef]

27. Shimabukuro, Y.E.; Arai, E.; Anderson, L.O.; de Aragão, L.E.O.eC.; Duarte, V. Mapping Degraded Forest Areas Caused By Fires During the Year 2010 in Mato Grosso State, Brazilian Legal Amazon Using Landsat-5 Tm Fraction Images. Rev. Bras. Cartogr. 2017, 69, 23-32.

28. Wagner, F.H.; Hérault, B.; Rossi, V.; Hilker, T.; Maeda, E.E.; Sanchez, A.; Lyapustin, A.I.; Galvão, L.S.; Wang, Y.; Aragão, L.E.O.C. Climate drivers of the Amazon forest greening. PLoS ONE 2017, 12, e0180932. [CrossRef]

29. Tyukavina, A.; Hansen, M.C.; Potapov, P.V.; Stehman, S.V.; Smith-Rodriguez, K.; Okpa, C.; Aguilar, R. Types and rates of forest disturbance in Brazilian Legal Amazon, 2000-2013. Sci. Adv. 2017, 3, 1-16. [CrossRef]

30. Shimabukuro, Y.E.; Miettinen, J.; Beuchle, R.; Grecchi, R.C.; Simonetti, D.; Achard, F. Estimating Burned Area in Mato Grosso, Brazil, Using an Object-Based Classification Method on a Systematic Sample of Medium Resolution Satellite Images. IEEE J. Sel. Top. Appl. Earth Obs. Remote Sens. 2015, 8, 4502-4508. [CrossRef]

31. Monitoramento da cobertura florestal da Amazônia por satélites: Sistemas PRODES, DETER, DEGRAD e Queimadas 2007-2008. Available online: https://www.google.com.hk/url?sa=t\&rct=j\&q=\&esrc=s\&source= web\&cd=8\&ved=2ahUKEwisou2mjenlAhVmG6YKHYfqC_kQFjAHegQIAxAC\&url=http\%3A\%2F\% 2Fwww.obt.inpe.br\%2Fprodes\%2FRelatorio_Prodes2008.pdf\&usg=AOvVaw2mYp1hD-ekxUCilvrALCRp (accessed on 14 September 2019).

32. Kalamandeen, M.; Gloor, E.; Mitchard, E.; Quincey, D.; Ziv, G.; Spracklen, D.; Spracklen, B.; Adami, M.; Aragão, L.E.O.C.; Galbraith, D. Pervasive Rise of Small-scale Deforestation in Amazonia. Sci. Rep. 2018, 8, 1600. [CrossRef]

33. Eva, H.; Huber, O.; Achard, F.; Balslev, H.; Beck, S.; Behling, H.; Belward, A.; Beuchle, R.; Cleef, A.; Colchester, M.; et al. A Proposal for Defining the Geographical Boundaries of Amazonia; Publications Office: Luxembourg, Belgium, 2005; ISBN 92-79-00012-8.

34. Projeto PRODES Monitoramento da Floresta Amazônica Brasileira por Satélite. Available online: http: //terrabrasilis.dpi.inpe.br/downloads (accessed on 1 January 2019).

35. Sample interpretation results, Brazilian Legal Amazon. Available online: https://glad.umd.edu/brazil/index. php (accessed on 1 January 2019).

36. R Core Team. R: A Language and Environment for Statistical Computing; R Foundation for Statistical Computing: Vienna, Austria, 2019.

37. Hesselbarth, M.H.K.; Sciaini, M.; With, K.A.; Wiegand, K.; Nowosad, J. Landscapemetrics: An open-source R tool to calculate landscape metrics. Ecography 2019, 42, 1648-1657. [CrossRef]

38. FAO. Map Accuracy Assessment and Area Estimation Map Accuracy Assessment and Area Estimation: A Practical Guide; FAO: Roma, Italy, 2016; p. 69.

39. Olofsson, P.; Foody, G.M.; Herold, M.; Stehman, S.V.; Woodcock, C.E.; Wulder, M.A. Good practices for estimating area and assessing accuracy of land change. Remote Sens. Environ. 2014, 148, 42-57. [CrossRef]

40. Picoli, M.C.A.; Camara, G.; Sanches, I.; Simões, R.; Carvalho, A.; Maciel, A.; Coutinho, A.; Esquerdo, J.; Antunes, J.; Begotti, R.A.; et al. Big earth observation time series analysis for monitoring Brazilian agriculture. ISPRS J. Photogramm. Remote Sens. 2018, 145, 328-339. [CrossRef]

41. UNFCCC. FCCC/CP/2009/11/Add.1, Decision 4/CP.15: Methodological Guidance for Activities Relating to Reducing Emissions from Deforestation and Forest Degradation and the Role of Conservation, Sustainable Management of Forests and Enhancement of Forest Carbon Stock; UN: New York, NY, USA, 2010.

42. Reducing Emission From Deforestation And Forest Degradation in Develping Countries - Web Platform. Available online: https://redd.unfccc.int/submissions.html (accessed on 1 January 2019).

(C) 2019 by the authors. Licensee MDPI, Basel, Switzerland. This article is an open access article distributed under the terms and conditions of the Creative Commons Attribution (CC BY) license (http://creativecommons.org/licenses/by/4.0/). 